DOI: $10.19195 / 0524-4544.328 .10$

\author{
MAREK PODKOWSKI \\ ORCID: 0000-0002-4128-1983 \\ Uniwersytet Wrocławski \\ marek.podkowski@uni.wroc.pl
}

\title{
Zmiany polskiego prawa samorządowego w 1938 roku
}

Ustawa o częściowej zmianie ustroju samorządu terytorialnego, określana w skrócie mianem „ustawy scaleniowej”, została uchwalona 23 marca 1933 roku ${ }^{1}$. Była ona jedną z najobszerniejszych i najważniejszych ustaw w dziedzinie prawa publicznego w II Rzeczypospolitej. Dotyczyła ona przede wszystkim zmiany ustroju, czyli organizacji władz samorządu terytorialnego.

Wprowadzenie w życie ustawy samorządowej, jak też normalna działalność ustawodawcza, zmusiła bądź spowodowała, że wiele jej postanowień zostało do wybuchu drugiej wojny światowej zmienionych. Sporo z nich uchwalono w 1938 roku, a więc tuż przed wybuchem drugiej wojny światowej.

Pierwszą chronologicznie ważniejszą zmianę w tym roku przyniosła ustawa z dnia 28 marca o zmianie rozporządzenia Prezydenta Rzeczypospolitej o ustroju miasta Gdyni ${ }^{2}$. W zamyśle twórców forma ustrojowa, uregulowana rozporządzeniem z 1930 roku, została wprowadzona na okres przejściowy i nie była ostateczna. Zakładano, że dopiero doświadczenia lat następnych pokażą, jaka forma ustrojowa będzie dobra dla tego pierwszego miasta portowego Polski ${ }^{3}$. Przewidziana przez rozporządzenie forma ustrojowa miała obowiązywać pięć lat, z możliwością przedłużenia jej na kolejne trzy lata. Tak też się stało. Rada Ministrów przedłużyła w 1935 roku komisaryczny ustrój Gdyni na dalsze trzy lata ${ }^{4}$. Wspomniana

1 Dz.U. Nr 35, poz. 294.

2 Dz.U. Nr 22, poz. 190.

3 M. Kardas, Gdynia i jej władze w latach 1926-1950. Główne problemy polskiej administracji publicznej miasta, Toruń 2013, s. 348.

4 Rozporządzenie Rady Ministrów z dnia 9 listopada 1935 roku o ustroju miasta Gdyni (Dz.U. $\mathrm{Nr} 83$, poz. 513). 
ustawa z 1938 roku określała, że zakres działania komisarza rządu w Gdyni miał odtąd obejmować prawa i obowiązki przełożonego gminy i starosty grodzkiego ${ }^{5}$. Skład rady miejskiej zmienił się dość istotnie, albowiem miała ona się składać z czterdziestu ośmiu radnych - trzydziestu dwu miało pochodzić z wyborów, a szesnastu mianował i odwoływał Minister Spraw Wewnętrznych w porozumieniu z Ministrem Przemysłu i Handlu ${ }^{6}$. Wprowadzono także novum — zarząd kolegialny składający się komisarza rządu i jego zastępcy oraz pięciu ławników wybieranych na powszechnie obowiązujących zasadach ${ }^{7}$. W myśl ustawy z 1938 roku uposażenie komisarza rządu i jego zastępcy składało się z pensji wypłacanej przez skarb państwa oraz dodatków pieniężnych wypłacanych z funduszy miejskich w wysokości określonej przez Ministra Spraw Wewnętrznych, działającego w porozumieniu z Ministrem Skarbu. Ustawa przedłużyła odrębny ustrój miasta Gdynia o kolejne pięć lat, do 29 listopada 1943 roku, z możliwością jego przedłużenia przez Radę Ministrów na dalsze trzy lata.

Kolejną istotną zmianę wprowadziła ustawa z dnia 31 marca 1938 roku o należnościach gmin z tytułu rozliczenia $\mathrm{z}$ właścicielami zniesionych obszarów dworskich $^{8}$. Przy wprowadzaniu w życie przepisów ustawy scaleniowej na obszarze województw poznańskiego i pomorskiego okazało się niezwykle istotne uregulowanie sprawy należności gmin z tytułu rozliczenia z właścicielami zniesionych obszarów dworskich. Ustawa scaleniowa zakładała, że nowo utworzone gminy miały prawo żądać od właścicieli zniesionych obszarów dworskich pewnych świadczeń jednorazowych lub stałych z tytułu zwolnienia właścicieli tych obszarów od wielu obowiązków ciążących na nich dotychczas w zakresie opieki społecznej, administracji drogowej, szkolnictwa, utrzymywania dotychczasowych wójtów i urzędów wójtowskich. Dokonanie rozrachunków i uregulowanie publicznoprawnych oraz majątkowych praw i obowiązków między właścicielami zniesionych obszarów dworskich, a gminami następowało w wyniku bezpośredniego porozumienia, a gdy porozumienie takie nie doszło do skutku, sprawę rozstrzygał wydział powiatowy ${ }^{9}$. Zasadniczą kwestią mającą duże znaczenie dla właściciela zniesionego obszaru dworskiego były sprawy komunikacji i socjalne (przejęcie dróg dworskich, utrzymanie osób ubogich z majątków dworskich itp. $)^{10}$.

W październiku 1935 roku wydziały powiatowe w województwach zachodnich zwróciły się do zarządów gmin, aby te jak najszybciej przystąpiły do

5 S. Podwiński, Teoria i dzieje samorządu terytorialnego, Łódź 1947, s. 163.

6 Poprzednia rada miejska składała się z dwudziestu członków. Spośród nich dziesięciu pochodziło z wyborów, a dziesięciu mianował i odwoływał Minister Spraw Wewnętrznych w porozumieniu z Ministrem Przemysłu i Handlu.

7 M. Kardas, op. cit., s. 352.

8 Dz.U. Nr 24, poz. 209.

9 Archiwum Państwowe w Poznaniu O. Gniezno, Akta gmin powiatu międzychodzkiego, gmina Chrzypsko Wielkie, sygn. 10, s. 4 n.

10 W. Dalbor, Nowy ustrój samorządu w województwach poznańskim i pomorskim, Poznań 1933, s. 73. 
rozliczenia między byłymi obszarami dworskimi a gminami. Chodziło bowiem o przejęcie czynności przez nowe gminy od obszarów dworskich, a także wójtostw i gmin dotychczasowych tak, aby nie spowodować żadnych przerw w administracji i wypełnianiu obowiązków publicznoprawnych. W tym celu tworzono także komisje likwidacyjne ${ }^{11}$, w której skład wchodzili dotychczasowy właściciel obszaru dworskiego, wójt nowo utworzonej gminy wiejskiej oraz członek rady gminnej, wybrany przez nią zwykłą większością głosów w obecności więcej niż połowy ustawowego składu rady ${ }^{12}$.

Ustawa z dnia 31 marca 1938 roku zapewniała gminom pierwszeństwo dochodzenia zobowiązań z tytułu rozliczeń z środków pieniężnych pochodzących ze sprzedaży nieruchomości wchodzących w skład zniesionego obszaru dworskiego (zaraz po należnościach skarbowych). Właściciele zniesionych obszarów dworskich mogli również w celu uregulowania zobowiązań przekazać na rzecz gminy odpowiednie uzgodnione z nią części gruntów. Wszystkie umowy między stronami oraz orzeczenia wydziału powiatowego dawały podstawę do wpisu hipotecznego. Ustawa z 1938 roku zastrzegła, że do czasu zawarcia umowy lub uprawomocnienia się orzeczenia właściciel zniesionego obszaru dworskiego musiał nadal ponosić świadczenia w rozmiarach i na zasadach, które obowiązywały go przed dniem 1 kwietnia 1935 roku.

Ustawa scaleniowa z 1933 roku w art. 38 przewidywała wydanie dla sześciu największych miast Polski, rozporządzeniami Prezydenta RP, odrębnych praw (statutów) o ustroju danego miasta. Prawo o ustroju miasta mogło indywidualizować ustrój jedynie w bardzo wąskim zakresie, ściśle wyliczonym w tymże art. 38 . Niestety żadne z sześciu miast, także Warszawa, odrębnego prawa o ustroju miasta nie otrzymały ${ }^{13}$. W tej sytuacji władze państwowe były zmuszone do wprowadzenia w życie na terenie miasta Warszawy bez żadnych zmian ustawy samorządowej z 1933 roku $^{14}$. Nie uwzględniała ona jednak konieczności istnienia odrębnego ustroju stolicy. Z tych między innymi powodów dojrzała potrzeba zasadniczego i trwałego unormowania organizacji stolicy, odrębnej od organizacji innych miast w Polsce. Wstrzymano więc wykonanie ogólnej ustawy scaleniowej w Warszawie i wydano rozporządzenie o tymczasowych organach ustrojowych gminy miasta stołecznego Warszawy ${ }^{15}$.

11 Powoływano je zgodnie z $§ 30$ ust. 1 rozporządzenia III Ministra Spraw Wewnętrznych z dnia 2 sierpnia 1934 roku w sprawie wykonania ustawy o częściowej zmianie ustroju samorządu terytorialnego (Dz.U. Nr 71, poz. 688).

12 Wydział powiatowy jednak zalecał, aby w miarę możliwości rada gminna wybrała takiego członka, który mógłby wejść do wszystkich komisji likwidacyjnych na terenie gminy.

13 Art. 38 ustawy scaleniowej stracił moc obowiązującą z dniem wejścia w życie nowej ustawy konstytucyjnej z 1935 roku, albowiem z chwilą wejścia w życie tej ustawy, przewidziane w ustawie scaleniowej pełnomocnictwa dla Prezydenta wygasły.

14 S. Podwiński, Teoria i dzieje samorządu terytorialnego, s. 153-154.

15 Rozporządzenie Prezydenta Rzeczypospolitej z dnia 24 września 1934 roku o tymczasowych organach ustrojowych gminy m.st. Warszawy (Dz.U. Nr 86, poz. 778). 
Powoływało ono do życia tymczasową organizację gminy, która miała istnieć do czasu wydania ustawy „o stołecznym samorządzie wojewódzkim”, nie dłużej niż do 31 marca 1936 roku. Rozporządzenie przewidywało, że zakres działania ustrojowych organów gminy przechodził na tymczasowy zarząd miejski, którego członkami byli prezydent miasta powoływany przez Radę Ministrów oraz pięciu wiceprezydentów powoływanych przez Ministra Spraw Wewnętrznych. Tymczasowy zarząd miejski pełnił kolegialnie funkcję organu stanowiącego gminy. Funkcjonowała również tymczasowa rada miejska, składająca się z trzydziestu sześciu członków mianowanych przez Ministra Spraw Wewnętrznych, mająca uprawnienia organu opiniodawczego we wszystkich sprawach, które w myśl ustawy scaleniowej należały do rady miejskiej. Do tymczasowych organów stolicy zaliczono komisję rewizyjną powoływaną także przez Ministra Spraw Wewnętrznych. Do jej zakresu działania należało wykonywanie kontroli wewnętrznej. Nie był to jednak organ pomocniczy tymczasowej rady miejskiej, lecz organ zupełnie niezależny, składający sprawozdania jedynie władzy nadzorczej.

Prace nad ustrojem samorządowym stolicy przedłużały się i dopiero w marcu 1936 roku rząd wniósł do sejmu projekt ustawy w tej sprawie. Jednocześnie skierował do sejmu projekt ustawy, uchwalony 30 marca 1936 roku, który przedłużył okres sprawowania czynności przez tymczasowe organy ustrojowe gminy miasta stołecznego Warszawy do 1 października 1937 roku $^{16}$. Trwająca dyskusja nad założeniami projektu spowodowała, że rząd i parlament zmuszone zostały do kolejnego przedłużenia okresu urzędowania tymczasowych organów ustrojowych stolicy do 1 października 1938 roku $^{17}$.

W styczniu 1938 roku Rada Ministrów przedstawiła kolejny projekt ustawy, mający charakter kompromisowy, który stał się podstawą do uchwalenia ustawy o samorządzie gminy miasta stołecznego Warszawy w dniu 16 sierpnia 1938 roku $^{18}$. Na jej mocy gmina miasta stołecznego Warszawa była jednostką samorządu terytorialnego gminnego, powiatowego i wojewódzkiego oraz osobą publicznoprawną. Ustawa bardzo szeroko zarysowała zakres działania miasta, ustalając, że należą do niego wszystkie sprawy dotyczące kultury, zdrowia i dobrobytu materialnego mieszkańców, jeżeli sprawy te nie zostały zastrzeżone aktami ustawodawczymi władzom rządowym, samorządowi gospodarczemu lub innym instytucjom prawa publicznego. W szczególności do zakresu działania należało: zarządzanie majątkiem miejskim oraz jego dochodami i wydatkami, zakładanie i utrzymywanie miejskich dróg, mostów, ulic, placów, ogrodów, zakładanie i utrzymywanie środków miejskiej komunikacji, zakładanie i utrzymywanie urządzeń służących do zaopatrywania mieszkańców w gaz, wodę, elektryczność, opieka społeczna, sprawy nadzoru budowlanego i rozbudowy miasta, popieranie

16 Dz.U. Nr 23, poz. 188.

17 Dz.U. Nr 48, poz. 371.

18 Dz.U. Nr 63, poz. 479. 
handlu, przemysłu i rzemiosła, szerzenie kultury i oświaty, tworzenie i utrzymywanie kas oszczędności. Organy miejskie pełniły też funkcje administracji rządowej oraz współdziałały w czynnościach innych organów państwowych.

Organami miasta w myśl ustawy były rada miejska, rady dzielnicowe i zarząd miejski. Rada miejska składała się z radnych i członków zarządu miejskiego. Kadencja jej trwała pięć lat. Uchwalona również 16 sierpnia 1938 roku ustawa o wyborze radnych miejskich ${ }^{19}$ zakładała, że stołeczna rada miasta będzie liczyć stu radnych. Zakres działania rady miejskiej, która była organem stanowiącym i kontrolującym, ustawodawca określił bardzo wyczerpująco w dwudziestu trzech punktach. W szczególności tworzyła normy i zasady dotyczące zarządu sprawami miasta i jego gospodarki, kontrolowała działalność zarządu miejskiego, powoływała komisje na okres kadencji. Na posiedzeniach rady miejskiej przewodniczył prezydent miasta lub wyznaczony przez niego wiceprezydent. Ustawa zawierała też wiele szczegółowych postanowień w sprawie sposobu zwoływania posiedzeń rady, sprawy quorum, większości niezbędnej do podjęcia ważnych uchwał, głosowania tajnego i imiennego, jawności i tajności obrad, przepisów porządkowych w stosunku do członków rady oraz publiczności itp. ${ }^{20}$

Ustawa realizowała jeden z postulatów wysuwanych od dawna w stosunku do ustroju Warszawy, a mianowicie dekoncentracji wewnętrznej władz miejskich. Powoływała do życia rady dzielnicowe oraz miejskie biura dzielnicowe. Ustawa samorządowa dla Warszawy z 1938 roku przewidywała podział miasta na dzielnice. Miała tego dokonać rada miejska uchwałą wymagającą zatwierdzenia Ministra Spraw Wewnętrznych. W razie nieprzeprowadzenia w ciągu sześciu miesięcy podziału na dzielnice przez radę miał tego dokonać Minister Spraw Wewnętrznych. W skład rady dzielnicowej wchodzili radni miejscy i ich zastępcy, wybrani w okręgach wyborczych z danej dzielnicy. Poza nimi w skład rady dzielnicowej wchodzili mieszkańcy dzielnicy niebędący radnymi miejskimi, powołani przez zarząd miejski w liczbie nie większej niż jedna trzecia członków rady dzielnicowej. Rada dzielnicowa wybierała swojego przewodniczącego, a także mogła spośród swoich członków powoływać komisje w celu przygotowania poszczególnych spraw. Do zadań rady dzielnicowej należało ustalanie potrzeb dzielnicy oraz opiniowanie spraw dotyczących dzielnicy. Ponadto rada miejska mogła uchwałą zatwierdzoną przez Ministra Spraw Wewnętrznych zwiększyć zakres działania poszczególnych albo wszystkich rad dzielnicowych, a także powołać dzielnicowe organy wykonawcze. Do wybuchu wojny miasto Warszawa nie zdążyło powołać rad dzielnicowych ${ }^{21}$.

Zarząd miejski był organem zarządzającym i wykonawczym miasta. Składał się z prezydenta miasta, pięciu wiceprezydentów oraz dziewięciu ławników. Prezydent i wiceprezydenci byli wybierani przez radnych miejskich na dziesięć

19 Dz.U. Nr 63, poz. 480.

20 S. Podwiński, Teoria i dzieje samorządu terytorialnego, s. 159.

21 M. Klimek, Samorzad miast II Rzeczypospolitej. Publiczna debata i rozwiązania ustrojowe, Lublin 2006, s. 75. 
lat. Zarząd działał kolegialnie — jako magistrat pod przewodnictwem prezydenta miasta albo jednoosobowo - przez prezydenta miasta. Zakres działania zarządu miasta został wyliczony w piętnastu punktach. W szczególności ustalał plan wykonania budżetu, ustanawiał opłaty za korzystanie z przedsiębiorstw, zakładów, instytucji i urządzeń miejskich, jak też opłaty administracyjne, przygotowywał sprawy, o których decydowała rada miejska.

Ustawa zawierała też przepisy dotyczące odpowiedzialności dyscyplinarnej pracowników. Przewidywały one powołanie dwuinstancyjnych komisji dyscyplinarnych i osiem rodzajów kar.

Największą władzę nadzorczą nad miastem Warszawa, choć nie jedyną, miał Minister Spraw Wewnętrznych. Środki nadzoru nie różniły się na ogół od tych, jakie były przewidziane przez ustawę scaleniową z 1933 roku w stosunku do innych miast ${ }^{22}$.

Ustawa z dnia 16 sierpnia 1938 roku w życie weszła częściowo. Wybrana została rada miejska, lecz nie wyłoniono nowego zarządu miejskiego. Do września 1939 roku działał w Warszawie dotychczasowy zarząd komisaryczny z prezydentem Stefanem Starzyńskim ${ }^{23}$.

Podstawowe zmiany w ustawie scaleniowej wprowadzone zostały w 1938 roku w zakresie prawa wyborczego do rad gromadzkich, gminnych i powiatowych oraz rad miejskich. W ustawie scaleniowej stosunkowo mało miejsca poświęcono na uregulowanie tych kwestii. Wszystkie kwestie szczegółowe w tym zakresie zawarte były w regulaminach wyborczych wydawanych jako rozporządzenia Ministra Spraw Wewnętrznych i ogłaszane w Dzienniku Ustaw. Wybory samorządowe przeprowadzone na podstawie tych regulaminów w latach 1933-1935 pokazały, że konieczna jest nowelizacja przepisów prawa wyborczego. Na podstawie tych doświadczeń rząd wniósł do sejmu w 1938 roku projekty ustaw zawierające przypisy wyborcze do rad gromadzkich, gminnych, powiatowych i miejskich ${ }^{24}$. Uchylone zostały wszystkie przepisy wyborcze obowiązujące dotychczas w myśl ustawy scaleniowej, a w ich miejsce weszły dwie ustawy z dnia 16 sierpnia 1938 roku o wyborze radnych gromadzkich, gminnych i powiatowych ${ }^{25}$ oraz o wyborze radnych miejskich ${ }^{26}$. Wiele jednak rozwiązań funkcjonujących do tego czasu znalazło się w nowych przepisach.

Przy wyborze radnych gromadzkich wprowadzono kilka istotnych zmian. Czynne prawo wyborcze przy wyborach do rady gromadzkiej według nowej ustawy się nie przekształciło, zmiana nastąpiła natomiast co do warunków biernego prawa wyborczego. Odtąd uprawniony do wybieralności był każdy obywatel ma-

\footnotetext{
22 S. Podwiński, Teoria i dzieje samorzadu terytorialnego, s. 161.

23 H. Izdebski, Samorzad terytorialny. Podstawy ustroju i działalności, Warszawa 2003, s. 55.

24 S. Podwiński, Teoria i dzieje samorzadu terytorialnego, s. 145-146.

25 Dz.U. Nr 63, poz. 481.

26 Dz.U. Nr 63, poz. 480.
} 
jący czynne prawo wyborcze, który przed dniem zarządzenia wyborów ukończył dwadzieścia siedem lat.

Podziału na okręgi wyborcze według ustawy z roku 1938 dokonywał starosta powiatowy przed zarządzeniem wyborów, ustalając jednocześnie dla każdego okręgu liczbę mandatów w zależności od liczby mieszkańców. W gromadach podzielonych na okręgi wyborcze na jeden okręg mogły przypaść co najmniej dwa mandaty. Starosta powiatowy zarządzał również wybory, podając dzień ich przeprowadzenia. Wybory przeprowadzały komisje wyborcze złożone z przewodniczącego, którego mianował starosta, oraz dwóch członków wybranych przez członków kolegium zarządu gminnego. Żadna osoba nie mogła bez usprawiedliwionych przyczyn sprzeciwić się przyjęciu funkcji członka komisji, chyba że kolegium zarządu gminnego zezwoliło na rezygnację z pełnienia tej funkcji. Do uprawnień wydziału powiatowego należało nakładanie na osobę, która się uchylała od przyjęcia funkcji członka komisji wyborczej, kary pieniężnej w wysokości od 10 do 100 złotych na rzecz gromady ${ }^{27}$. Wprowadzono też wymóg wybrania zastępców przewodniczącego i członków komisji wyborczej. Zastępcom służyło prawo obecności na posiedzeniach właściwych komisji, a w głosowaniu tylko w razie nieobecności osób, które reprezentowały. Do ważności uchwał komisji wyborczej niezbędna była obecność przewodniczącego i dwóch członków komisji. Uchwały zapadały zwykłą większością głosów osób obecnych, a w razie równości przeważał głos przewodniczącego. Wójt sporządzał spisy wyborców, które były następnie wyłożone w lokalu gromadzkiej komisji wyborczej przez okres trzech dni. Kandydatów na radnych gromadzkich mogło zgłosić dziesięciu wyborców, jednak liczba zgłoszonych nazwisk musiała wynieść podwójną liczbę mandatów przypadających na daną gromadę. Czas głosowania został wydłużony do dziesięciu godzin i było ono tajne. Wyborca mógł jednak oddać swój głos przez wskazanie ustnie do protokołu nazwisk kandydatów ${ }^{28}$.

Także przy wyborze rady gminy większość postanowień poprzednio obowiązującego regulaminu pozostawiono w mocy. Według ustawy z 1938 roku każda lista kandydatów musiała być podpisana własnoręcznie lub zgłoszona osobiście do protokołu komisji wyborczej przez co najmniej dziesięciu członków gminnego kolegium wyborczego $\mathrm{w}$ gminach nie podzielonych na okręgi wyborcze i pięciu członków okręgowego kolegium wyborczego w okręgach wyborczych. W trakcie głosowania wyborca dysponował taką liczbą głosów, ilu radnych wybierało kolegium wyborcze. Mógł również oddać swoje głosy na mniejszą liczbę kandydatów na radnych, rezygnując $w$ ten sposób z pozostałych głosów ${ }^{29}$. Inny był też rozdział mandatów pomiędzy listy kandydatów. Dokonywała go komisja wyborcza

27 Kary pieniężne nakładane na członków komisji wyborczych ściągało się w trybie postępowania przymusowego $\mathrm{w}$ administracji.

28 S. Podwiński, Ustawa samorzadowa z komentarzem, Warszawa 1939, s. 87.

29 Dz.U. Nr 63, poz. 481. 
w następujący sposób: ogólną liczbę ważnych głosów oddanych na kandydatów każdej listy dzielono kolejno przez 1, 2, 3 itp., aż dało się uszeregować tyle kolejno największych liczb (ilorazów), ile mandatów było do obsadzenia. Poszczególnej liście kandydatów przyznawano tyle mandatów, ile liczb (ilorazów) przypadało na nią spośród ustalonego w ten sposób szeregu. O przyznaniu mandatu jednej z kilku list wykazujących jednakowe ilorazy końcowe rozstrzygał los wyciągnięty przez przewodniczącego. O pierwszeństwie i kolejności wyboru poszczególnych kandydatów na radnych $\mathrm{z}$ danej listy rozstrzygała kolejna względna większość ważnie oddanych głosów na kandydatów tej listy. W przypadku oddania jednakowej liczby głosów na kilku kandydatów o pierwszeństwie uzyskania mandatu rozstrzygał również los wyciągnięty przez przewodniczącego ${ }^{30}$.

Jeśli po obliczeniu głosów lista nie otrzymała ani jednego mandatu, a liczba głosów oddana na któregokolwiek kandydata takiej listy przekraczała połowę wspólnego ilorazu wyborczego dla całego okręgu, to ów kandydat otrzymywał mandat radnego przypadający innej liście, lecz nieobsadzony w myśl tych przepisów. Gdy jednak wszystkie mandaty zostały obsadzone, to kandydat, który z listy nieuprawnionej do żadnego mandatu skupił ponad połowę wspólnego ilorazu wyborczego dla całego okręgu, otrzymywał mandat zamiast kandydata, który z innej listy uzyskał mniejszą liczbę głosów i przy tym najmniejszą spośród kandydatów innych list. Jeśli kilka list lub kilku kandydatów z innych list odpowiadałoby jednakowym warunkom uzasadniającym utratę mandatu, wówczas traciła mandat lista albo kandydat z listy, która otrzymała najmniejszą liczbę głosów, a przy równej liczbie głosów otrzymanej przez kilka list o utracie mandatu rozstrzygał los wyciągnięty przez przewodniczącego. Wspólny iloraz wyborczy dla całego okręgu uzyskiwano przez podzielenie wszystkich ważnie oddanych głosów na kandydatów wszystkich list przez liczbę przypadających na okręg mandatów.

Według nowych przepisów komisja wyborcza wyniki wyborów ogłaszała dzień po głosowaniu w sposób w danej miejscowości przyjęty oraz przez wywieszenie przed mieszkaniem sołtysów i budynkiem urzędu gminy. Ponadto jeżeli w ciągu kadencji liczba zastępców radnych została wyczerpana, a liczba radnych zmniejszyła się nie więcej niż o $25 \%$, to starosta powiatowy mógł zarządzić nowe wybory uzupełniające. Był natomiast obowiązany je zarządzić, jeżeli liczba radnych zmniejszyła się o więcej niż o $25 \%$.

Według ustawy z dnia 16 sierpnia 1938 roku radnych powiatowych wybierały w głosowaniu tajnym kolegia wyborcze, złożone $\mathrm{z}$ radnych i członków zarządu gmin wiejskich i miast niewydzielonych z powiatowych związków samorządowych. Każda gmina wiejska i miasto liczące do 10 tys. mieszkańców wybierało po dwu radnych powiatowych. Miasta większe dodatkowo wybierały po jednym radnym na każde rozpoczęte 5 tys. mieszkańców, nie więcej niż pięciu

30 Ibidem. 
radnych $^{31}$. Do ważności wyborów niezbędna była obecność więcej niż połowy ustawowej liczby członków danego kolegium wyborczego. Kolegium wyborcze mogło obejmować wyborców z jednej gminy lub dwu i więcej gmin wiejskich bądź miejskich. Decyzje w tej sprawie podejmował wojewoda. Bierne prawo wyborcze przysługiwało każdemu, kto mieszkał na obszarze danego powiatu i dzień przed zarządzeniem wyborów odpowiadał warunkom wybieralności na radnego gminnego lub radnego miejskiego oraz potrafił czytać i pisać w języku polskim.

Wybory zarządzał wojewoda. Dla każdego kolegium wyborczego były powoływane komisje wyborcze. Przewodniczącym komisji był przełożony danej gminy, a dwu pozostałych członków komisji wybierało kolegium wyborcze. Wyborcy zgłaszali kandydatów w okręgach dwumandatowych, a listy kandydatów w okręgach o większej liczbie mandatów. Przy wyborze dwu radnych wyborca mógł głosować tylko na jednego z ważnie zgłoszonych kandydatów. Za wybranych uznawano w tym przypadku tych kandydatów, którzy otrzymali największą liczbę głosów, co najmniej po $20 \%$ wszystkich ważnych głosów ${ }^{32}$. W razie konieczności przeprowadzano uzupełniające głosowanie. Natomiast przy wyborze trzech lub więcej radnych powiatowych głosowało się nie na listy kandydatów, lecz na nazwiska z list, to znaczy wyborca na karcie wyborczej mógł podać jedno nazwisko kandydata $z$ jednej listy, drugie z innej itp. Przy wyborze trzech i więcej radnych powiatowych wyborca rozporządzał taką liczbą głosów, ilu radnych wybierało kolegium wyborcze. Jednemu kandydatowi mógł oddać jeden głos ${ }^{33}$. Przy podziale mandatów listom kandydatów stosowano zasadę proporcjonalności. Od tej zasady przewidziano jednak odstępstwo. Ustawodawca przyznał też mandat najpopularniejszemu kandydatowi z listy, która nie miała prawa do mandatu, jeżeli kandydat taki otrzymał więcej niż połowę głosów ogólnej liczby wyborców. Odbywało to się kosztem najsłabszego kandydata z najsłabszej z list uprawnionej do mandatu ${ }^{34}$.

Przepisy dotyczące wyboru radnych powiatowych nie odbiegały znacznie od zasad zawartych w ustawie scaleniowej z 1933 roku. Z ważniejszych zmian należy wymienić: tajność głosowania, powoływanie członków komisji wyborczej z wyboru, a nie z nominacji przez przewodniczącego, inne zasady głosowania przy wyborze trzech lub więcej radnych i przywilej najpopularniejszego kandydata.

Drugą ustawą w tym zakresie była wspomniana już ustawa z dnia 16 sierpnia 1938 roku o wyborze radnych miejskich. Zawierała ona przepisy wyborcze dla wszystkich miast, łącznie z Warszawą. Ustawa podtrzymywała w zasadzie reguły wyborcze określone w ustawie scaleniowej z 1933 roku $^{35}$. W celu przeprowadzenia wyborów władze administracji ogólnej dzieliły teren miasta na okręgi wybor-

31 Dz.U. Nr 63, poz. 481.

32 S. Podwiński, Teoria i dzieje samorzadu terytorialnego, s. 149.

33 S. Podwiński, Ustawa samorządowa z komentarzem, s. 158.

34 Ibidem, s. 159.

35 S. Podwiński, Teoria i dzieje samorzadu terytorialnego, s. 149. 
cze, a na każdy okręg przydzielały zależną od liczby mieszkańców okręgu liczbę mandatów ${ }^{36}$. Obowiązujące do tej pory przepisy zakładały, że okręg wyborczy musi mieć co najmniej trzy mandaty, a górna liczba nie była określona. Ustawa z 1938 roku przewidywała tworzenie okręgów od jednego do ośmiu mandatów. Przewidywała ona też, że w okręgach jedno- i dwumandatowych wyborca może głosować tylko na jednego kandydata na radnego. $\mathrm{Z}$ kolei w okręgach o trzech lub więcej mandatach wyborca miał tyle głosów, ilu radnych wybierano w okręgu wyborczym. Mógł jednak oddać swoje głosy na mniejszą liczbę kandydatów na radnych, rezygnując w ten sposób z pozostałych swych głosów. W okręgach o trzech lub więcej mandatach wyborca mógł głosować na nazwiska kandydatów danego okręgu bez względu na to, na jakich listach kandydatów nazwiska te były umieszczone.

Nowe przepisy wyborcze do rad miejskich zniosły obowiązujące wcześniej prawo kumulacji głosów. Dawniej wyborca mógł oddać wszystkie głosy na jedną osobę, po zmianie przepisów wyborca mógł oddać na kandydata na radnego jeden głos. Zmienił się także skład komisji wyborczej. Ustawa z 1938 roku zakładała, że składały się one z przewodniczącego i czterech członków. Przewodniczącego i jednego członka powoływały władze administracji rządowej, a trzech członków wybierał magistrat. Nowością było umożliwienie wyborcom kontroli wyborów przez prawo udziału ich mężów zaufania (pełnomocników) w komisjach wyborczych. Pełnomocnicy zgłaszali listy kandydatów, usuwali braki w tych listach, byli obecni przy oddawaniu i obliczaniu głosów ${ }^{37}$. Istotną zmianą w ustawie z 1938 roku było wprowadzenie zasady, że rozpatrywanie protestów wyborczych powierzono wydziałowi powiatowemu lub wydziałowi wojewódzkiemu.

Ustawa w wyborze radnych miejskich zawierała wiele przepisów o sposobie zarządzania wyborów, o trybie powoływania komisji wyborczych, sporządzaniu spisu wyborców, wyłożeniu spisów i wnoszeniu reklamacji. Nadal obowiązywała zasada fakultatywnego podziału na okręgi miast liczących do 5 tys. mieszkańców i przymusowego podziału miast o większym zaludnieniu ${ }^{38}$. Wybory do rady miejskiej jak dotychczas były powszechne, równe, tajne i bezpośrednie na nazwiska kandydatów.

Ustawa regulowała również przypadki, gdy wybory odbywały się bez głosowania, ponieważ w okręgu dokonane było tylko jedno zgłoszenie lub zgłoszona była tylko jedna lista kandydatów. Określała także sposób sporządzania protokołów wyborczych, ustalania i ogłaszania wyników wyborów, sposób składania protestów wyborczych oraz unieważniania wyborów z urzędu ${ }^{39}$.

Po wejściu w życie ustawy o wyborze radnych gromadzkich, gminnych i powiatowych oraz ustawy o wyborze radnych miejskich właściwe władze zaczęły zarządzać wybory. Niestety ustawa scaleniowa z 1933 roku, tworząc nowe

36 A. Wereszczyński, Wiadomości o Polsce współczesnej, cz. 1, Lwów 1935, s. 235.

37 S. Podwiński, Teoria i dzieje samorządu terytorialnego, s. 150.

38 S. Podwiński, Ustawa samorzadowa z komentarzem, s. 107.

39 Dz.U. Nr 63, poz. 480. 
gminy wiejskie, spowodowała, że w różnych terminach w poszczególnych częściach Polski zarządzono wybory. W związku z tym kadencja dotychczasowych organów upływała nie w jednym czasie. Konieczne zatem stało się ujednolicenie terminów wygasania kadencji organów samorządowych na obszarze całego państwa. W tym celu 22 listopada 1938 roku wydany został przez Prezydenta Rzeczypospolitej dekret o skróceniu kadencji niektórych organów ustrojowych w samorządzie terytorialnym ${ }^{40}$. Dekretem skrócono kadencje organów gromadzkich, gminnych i powiatowych na obszarze województw południowych i zachodnich, jak również kadencje rad miejskich, jeżeli kończyła się po 1 stycznia 1941 roku. Po wejściu w życie tego dekretu z wyjątkiem nielicznych miast na całym obszarze państwa miało nastąpić całkowite odnowienie organów samorządowych od jesieni 1939 roku. Wybuch drugiej wojny światowej przerwał ten proces wyborczy ${ }^{41}$.

Opisane zmiany były ostatnimi, ważniejszymi regulacjami w prawie samorządowym przed wybuchem drugiej wojny światowej. Rok 1939 nie przyniósł istotnych zmian w tej materii. Należy podkreślić, że dokonanie tych zmian wymusiły na ustawodawcy doświadczenia lat ubiegłych, praktyczne stosowanie tych norm. Zwłaszcza czynności związane z wyborami radnych gromadzkich, gminnych, miejskich i powiatowych były bardzo istotne i poświęcano im wiele miejsca. Zasady wyborcze były nadal skomplikowane i przysparzały sporo problemów zwłaszcza organom samorządowym niższego szczebla.

\section{Bibliografia}

\section{Źródła archiwalne}

Archiwum Państwowe w Poznaniu O. Gniezno, Akta gmin powiatu międzychodzkiego, gmina Chrzypsko Wielkie, sygn. 10.

\section{Akty normatywne}

Dekret Prezydenta Rzeczypospolitej z dnia 22 listopada 1938 roku o skróceniu kadencji niektórych organów ustrojowych w samorządzie terytorialnym (Dz.U. Nr 91, poz. 625).

Rozporządzenie Ministra Spraw Wewnętrznych z dnia 2 sierpnia 1934 roku w sprawie wykonania ustawy o częściowej zmianie ustroju samorządu terytorialnego (Dz.U. Nr 71, poz. 688).

Rozporządzenie Prezydenta Rzeczypospolitej z 24 września 1934 roku o tymczasowych organach ustrojowych gminy m.st. Warszawy (Dz.U. Nr 86, poz. 778).

Rozporządzenie Rady Ministrów z dnia 9 listopada 1935 roku o ustroju miasta Gdyni (Dz.U. Nr 83, poz. 513).

40 Dz.U. Nr 91, poz. 625.

41 S. Podwiński, Teoria i dzieje samorządu terytorialnego, s. 151. 
Ustawa z dnia 23 marca 1933 roku o częściowej zmianie ustroju samorządu terytorialnego (Dz.U. Nr 35, poz. 294).

Ustawa z dnia 30 marca 1936 roku o przedłużeniu okresu urzędowania tymczasowych organów ustrojowych gminy m.st. Warszawy (Dz.U. Nr 23, poz. 188).

Ustawa z dnia 22 czerwca 1937 roku o przedłużeniu okresu urzędowania tymczasowych organów ustrojowych gminy m.st. Warszawy (Dz.U. Nr 48, poz. 371).

Ustawa z dnia 28 marca 1938 roku o zmianie rozporządzenia Prezydenta Rzeczypospolitej o ustroju miasta Gdyni (Dz.U. Nr 22, poz. 190).

Ustawa z dnia 31 marca 1938 roku o należnościach gmin z tytułu rozliczenia z właścicielami zniesionych obszarów dworskich (Dz.U. Nr 24, poz. 209).

Ustawa z dnia 16 sierpnia 1938 roku o samorządzie gminy m.st. Warszawy (Dz.U. Nr 63, poz. 479).

Ustawa z dnia 16 sierpnia 1938 roku o wyborze radnych gromadzkich, gminnych i powiatowych (Dz.U. Nr 63, poz. 481).

Ustawa z dnia 16 sierpnia 1938 roku o wyborze radnych miejskich (Dz.U. Nr 63, poz. 480).

\section{Literatura}

Dalbor W., Nowy ustrój samorządu w województwach poznańskim i pomorskim, Poznań 1933.

Izdebski H., Samorząd terytorialny. Podstawy ustroju i działalności, Warszawa 2003.

Kardas M., Gdynia i jej władze w latach 1926-1950. Główne problemy polskiej administracji publicznej miasta, Toruń 2013.

Klimek M., Samorząd miast II Rzeczypospolitej. Publiczna debata i rozwiazania ustrojowe, Lublin 2006.

Podwiński S., Teoria i dzieje samorządu terytorialnego, Łódź 1947.

Podwiński S., Ustawa samorządowa z komentarzem, Warszawa 1939.

Wereszczyński A., Wiadomości o Polsce współczesnej, cz.1, Lwów 1935.

\section{Changes in the Polish local government law in 1938}

\section{Summary}

The article presents the most important changes in the Polish local government law introduced in 1938. They were the last major regulations in this respect before the outbreak of the Second World War. They resulted from regular legislative activities as well as experiences of previous years with applying such legal solutions. The regulations concerned the status of the cities of Gdynia and Warsaw; receivables of municipalities from the settlements of accounts with the owners of the abolished areas under landowners' rule; elections to village, commune, city and district councils; as well as shortening of the term in office of some local government bodies.

Keywords: local government law, local government 


\section{Änderungen des polnischen Selbstverwaltungsrechtes von 1938}

\section{Zusammenfassung}

Der Aufsatz stellt die wichtigeren, im Jahre 1938 eingeführten Änderungen im polnischen Selbstverwaltungsrecht vor. Es waren die letzten wesentlichen Regulierungen in diesem Bereich vor dem Ausbruch des Zweiten Weltkrieges. Diese waren verursacht durch normale gesetzgebende Tätigkeit und Erfahrungen der letzten Jahre bei Anwendung dieser rechtlichen Entscheidungen. Sie betrafen die Struktur der Städte Gdingen und Warschau, die den Gemeinden auf Grund der Abrechnung mit den Eigentümern der abgetragenen Hofgebiete geschuldeten Beträge, die Wahlen in die Räte der Gromaden, Gemeinden, Städte und Kreise sowie die Kürzung der Amtsperiode einiger struktureller Organe der territorialen Selbstverwaltung.

Schlüsselworte: selbstverwaltendes Recht, territoriale Selbstverwaltung 